\title{
KARYOTYPE ALTERATIONS AFTER HYBRIDIZATION BETWEEN Pennisetum purpureum AND Pennisetum glaucum
}

\author{
Alterações cariotípicas após hibridização entre Pennisetum purpureum e Pennisetum glaucum
}

\author{
Gabriela Barreto dos Reis ${ }^{1}$, Larissa Fonseca Andrade-Vieira ${ }^{1}$, José Marcello Salabert de Campos ${ }^{2}$, \\ Antonio Vander Pereira ${ }^{3}$, Lisete Chamma Davide ${ }^{4}$
}

\begin{abstract}
Napier grass and pearl millet are tropical forages from the genus Pennisetum. The variability in those species is explored in breeding programs of forages, as well as in the production of interspecific hybrids. Hybridization is a phenomenon that leads to intergenomic conflicts following the elimination of genomic sequences. In this sense, the present work aimed to study the genomic alterations occurring after interspecific hybridization of pearl millet and Napier grass with the use of cytogenetics and flow cytometry tools. These methods allowed the evaluation of chromosome morphometry, DNA content and genomic ratio in pearl millet, Napier grass and hybrids. It was observed that pearl millet and Napier grass have chromosomes with superposed size. The hybrid presents chromosomes that are smaller than expected, leading to karyotype alterations. Additionally, comparing the DNA content of parents and hybrids, loss of DNA content was demonstrated. Further, changes in the pearl millet and Napier grass genome ratio were also verified in the hybrid nucleus. Moreover, genomic rearrangements were shown to occur through karyotype alterations in the hybrid.
\end{abstract}

Index terms: Interspecific hybrids; chromosome morphology; DNA content; in situ hybridization.

\section{RESUMO}

O capim-elefante e o milheto são forragerias tropicais pertencentes ao gênero Pennisetum. A variabilidade existente dentro de cada uma dessas espécies é explorada no melhoramento de forragens, assim como na hibridização interespecífica entre elas. A hibridização interespecífica é um fenômeno que pode levar a conflitos intergenômicos, ocasionando a eliminação de sequências genômicas, assim como rearranjos cromossômicos. Objetivo-se, do presente trabalho, estudar as possíveis alterações cariotípicas nos cromossomos da combinação híbrida. Para tanto, os cromossomos dos parentais, capim-elefante e milheto, e do híbrido interespecífico foram analisados, por meio de técnicas de citogenética, e os genomas por citometria de fluxo. Foi avaliada a morfometria dos cromossomos dessas espécies, seu conteúdo de DNA e as proporções genômicas dos parentais no híbrido. O capim-elefante e o milheto apresentaram tamanhos cromossômicos sobrepostos, e o híbrido avaliado apresentou cromossomos com comprimento menor do que o esperado. Adicionalmente, comparando-se o híbrido com os parentais foi possível identificar perda no conteúdo de DNA e alteração na relação dos genomas parentais no núcleo híbrido. Além disso, foi demonstrada a ocorrência de rearranjos genômicos, por meio das alterações cariotípicas no híbrido.

Termos para indexação: Híbridos interespecíficos; morfometria cromossômica; conteúdo de DNA; hibridização in situ.

\section{INTRODUCTION}

Napier grass and pearl millet are two forage plants from the genus Pennisetum (Martel et al., 2004). Napier grass (P. purpureum) is an alogamous, perennial, allopolyploid species with $2 \mathrm{n}=4 \mathrm{x}=28$ chromosomes and genomes A'A'BB. Pearl millet $(P$. glaucum) is an annual diploid plant with $2 \mathrm{n}=2 \mathrm{x}=14$ chromosomes and genomes AA (Martel et al., 1997; Martel et al., 2004). The variability existing within each of these species is explored in genetic breeding, as well as in the interspecific hybridization between them.
The resulting hybrid is a sterile triploid with $2 \mathrm{n}=3 \mathrm{x}=21$ chromosomes and genomes A A'B. This hybrid has been explored in breeding programs of Napier grass so as to improve foraging quality, as it allows uniting favorable characteristics of both parents (Hanna, 1999; Barbosa; Davide; Pereira, 2003; Campos et al., 2009). In the hybrid, the elevated production of dry mass, good palatability, high nutritious value and perenniality of the Napier grass are combined with the forage quality, good resistance to drought and diseases, tolerance to low fertility levels of the soil, production of indehiscent seeds and larger size of the millet, generating genotypes that are superior to the parents (Hanna, 1999; Pereira et al., 2000; Pereira et al., 2003).

1 Universidade Federal de Lavras/UFLA - Departamento de Biologia/DBI - Lavras - MG - Brasil

${ }^{2}$ Universidade Federal de Juiz de Fora/UFJF - Departamento de Biologia - Instituto de Ciências Biológicas/ICB - Juiz de Fora - MG - Brasil

${ }^{3}$ Empresa Brasileira de Pesquisas Agropecuárias/EMBRAPA - Embrapa Gado de Leite - Juiz de Fora - MG - Brasil

${ }^{4}$ Universidade Federal de Lavras/UFLA - Departamento de Biologia/DBI - Campus Universitário - Caixa Postal 3037 - $372000-000$ - Lavras - MG -

Brasil - lisete.ufla@gmail.com

Received in december 10, 2014 and approved in may 4, 2015

Ciênc. Agrotec., Lavras, v. 39, n. 5, p. 443-454, set./out., 2015 
Nevertheless, despite its advantages, hybridization also has genomic consequences. The reunion of two genomes in a single nucleus results in intergenomic conflicts, leading to genetic and epigenetic reorganizations (Riddle; Birchler, 2003). This has been evidenced in works carried out with natural and synthetic hybrids, which have demonstrated that the new genomic constitution, resulting from hybridization, leads to elimination of DNA sequences (Feldman et al., 1997; Shaked et al., 2001; Leitch; Bennett, 2004; Leão et al., 2011; Nunes et al., 2013), chromosome rearrangements (Pires et al., 2004; Pontes et al., 2004; Udall; Quijada; Osborn, 2005), chromosome elimination (Germand et al., 2005; Ishii et al., 2010; Sanei et al., 2011; Andrade-Vieira et al., 2013), epigenetic alterations such as methylation of coding and non-coding DNA sequences (Levy; Feldman, 2004; Salmon; Ainouche; Wendel, 2005; Lukens et al., 2006), gene silencing (Lee; Chen, 2001; Doyle et al., 2008; Gaeta et al., 2007;) and activation of genes and retroelements that alter the expression of adjacent genes (Adams; Wendel, 2005; Kashkush; Feldman; Levy, 2002, 2003).

In the case of triploid hybrids of elephant grass and pearl millet, they are somatically stable in respect of chromosome number (Barbosa; Davide; Pereira, 2003), but they have generally lower length of chromosome complement and DNA content than expected in relation to their parents (Barbosa; Davide; Pereira, 2003; Leão et al, 2011;. Nunes et al, 2013). However, until this time, it had not been showed what are the changes that occur in karyotype of these hybrids that explain these reductions.

In this sense, the aim of the present study was to assess the karyotype alterations in the chromosomes complement of the hybrid combination resulting from interspecific hybridization process. It is expected that the results, obtained by integrating cytogenetic and flow cytometry techniques, will provide information for future studies to help understand the rearrangements arising from genomic conflicts due to the interspecific hybridization between Napier grass and pearl millet.

\section{MATERIAL AND METHODS}

\section{Genetic material}

For analysis of genomic alterations after interspecific hybridization between Napier grass and pearl millet, two triploid hybrids and their respective parents were evaluated: triploid hybrid 1 (H1) from the crossing between BAG 54 (Napier grass) and M 36 (pearl millet), named 94-43-2; and triploid hybrid 2 (H2), resulting from the crossing between BAG 63 (Napier grass) and M 36 (pearl millet), named 94-44-3. Pearl millet (M 36) was used as female parental in both crosses. The crosses and the plant material were performed and provided by the Active Germplasm Bank of Elephant Grass (BAGCE) from Embrapa Dairy Cattle Elephant Grass Breeding Program, experimental field José Henrique Bruschi, city of Coronel Pacheco, Minas Gerais, Brazil.

\section{Obtention of chromosomes}

Roots obtained from plantlets grown from cuttings and/or seeds of the parents and the interspecific hybrids were collected, treated, and slides were prepared according to Andrade-Vieira et al. (2013).

\section{Morphometric analysis of chromosomes}

For the morphometric analysis of the chromosomes, the obtained slides were stained with $5 \%$ Giemsa solution for $3 \mathrm{~min}$ and evaluated under light microscope. The images of at 5 metaphases from each genotype (M 36, BAG 54, BAG 63, H1 and H2) with chromosomes well spread and showing well-defined centromere, were captured with a Leica DMLS equipped with a microcamera (Nikon Digital Sight DS-Fi1). The images were digitized with the program Optronics ${ }^{\circledR}$.

The morphometric data were obtained with the program Image Tool for Windows version 3.0. It was obtained through analysis: (1) the average total length of the chromosome i (TLi), (2) length of the short arm (SA) and long arm (LA), (3) arms ratio (AR $=\mathrm{LA} / \mathrm{SA})$, (4) centromeric index $(\mathrm{CI}=\mathrm{SA} \times 100 / \mathrm{TL})$ and (5) relative length of the chromosomes $[\mathrm{RL}=(\mathrm{SA}+\mathrm{LA}) / \mathrm{TL}]$. The total length of the haploid lot (TLHL) was obtained by the half of the total sum of each pair of chromosomes to parental Napier grass and pearl millet $\left(\mathrm{TLHL}=\sum \mathrm{TLi} / 2\right)$. For the hybrids, the TLHL was calculated as the sum of the average total length of each chromosome $\left(\mathrm{TLHL}=\sum \mathrm{TLi}\right)$. The classification of the chromosomes was based on the arms ratio (long/short), in accordance with Guerra (1986).

The measurements obtained from the five metaphases were used to construct an ideogram, which were used in the discussion of karyotype alterations.

\section{Genomic In Situ Hybridization (GISH)}

In order to define the size of the chromosomes of each parent in the hybrids, five metaphases of the triploid hybrid BAG 65 (Napier grass) and BN 2 (pearl millet) were hybridized with a genomic probe of pearl millet. The millet chromosomes identified in the metaphases, as well as the other chromosomes from Napier grass were measured with the program Image Tool for Windows, version 3.0. The total length of each parental chromosomes identify in the 
hybrid was used to compare the proportions of the genomes of Napier grass and pearl millet in the hybrid nucleus.

Genomic DNA from millet was isolated using the method described by Doyle and Doyle (1987). The DNA was applied as probe after labeling with biotin-16deoxyuridine 5-triphosphate (Roche Applied Science) using the nick translation reaction method (Invitrogen Corporation). The Genomic in situ hybridization (GISH) methodology was followed Andrade-Vieira et al. (2013).

Images of GISH metaphases from the hybrid were captured with a Nikon Coolpix digital camera mounted on a Nikon Eclipse EC400 fluorescence microscope (Nikon Corporation). The images were processed using the Adobe Photoshop version 6.0 software (Adobe Systems, 2000).

\section{Analysis of DNA content}

For estimating the nuclear DNA content, three samples of each genotype (M 36, BAG 54, BAG 63, H1 and $\mathrm{H} 2$ ) were analyzed by flow cytometry according to methodology described by Campos et al. (2009).

\section{RESULTS AND DISCUSSION}

The morphometric analysis of the chromosomes of Napier grass and pearl millet is summarized in the Table 1. The average length of the TLHL between the Napier grass genotype was $44.43 \mu \mathrm{m}$ whereas the TLHL for pearl millet genotype was $31.57 \mu \mathrm{m}$.

The differences in the values of the TLHL between elephant grass genotypes (BAG 54 and BAG 63) are consistent with the differences observed in DNA content values. If the ratio between the smallest and largest values of TLHL and DNA content are considered the indices obtained are 0.97 and 0.99 , respectively.

The variation in the total length of the chromosomes from interspecific hybrids $\mathrm{H} 1$ (BAG 54 x M 36) and $\mathrm{H} 2$ (BAG $63 \times$ M 36) as far as the 2C DNA content in the somatic cells is presented in Table 2. It is interesting to emphasize that due to hybrid condition of these genotypes, for calculating the TLHL were considered all 21 chromosomes, since the three genomes are present (AA'B) in single doses in the somatic cells. For the hybrids, no correlation between the ratio of the smallest and largest values of TLHLs and DNA content was observed. This is probably due the influence of the different degrees of condensation between the analyzed metaphases.

Previously, Barbosa, Davide and Pereira (2003) evaluated the morphometry of chromosomes in five accessions from each genotype in question (Napier grass, millet and triploid hybrid). The authors obtained a mean TLHL of
$28.11 \mu \mathrm{m}$ for Napier grass, $28.36 \mu \mathrm{m}$ for millet, and $47.69 \mu \mathrm{m}$ for the interspecific hybrid. These results differ from the mean chromosome sizes and TLHL found in the present work, as shown in Tables 1 and 2. These differences in relation to the measures of the chromosomes are inherent to the condensation patterns observed here and by other authors. Comparing the condensation of the metaphases presented here with those from the work of Barbosa, Davide and Pereira (2003), it can be verified that the present metaphases are slightly less condensed.

In turn, the estimates for DNA content observed here for Napier grass and pearl millet (Tables 1 and 2, $4.54 \mathrm{pg}$ and $4.75 \mathrm{pg}$, respectively) corroborate the results obtained by Martel et al. (1997), in which the DNA amount per somatic cell (2C) was close to 4.59 pg for Napier grass and $4.71 \mathrm{pg}$ for pearl millet. According to these authors, the chromosomes of Napier grass display half the size of millet chromosomes, because the DNA amount per chromosome lot (represented by the basic number $\mathrm{x}=7$ ) is $1.15 \mathrm{pg}$ and $2.36 \mathrm{pg}$, for Napier grass $(4 \mathrm{x})$ and millet $(2 \mathrm{x})$, respectively. This affirmation has also been made by Barbosa, Davide and Pereira (2003) based on data of TLHL.

However, it was observed in the present work that the tetraploid genome of Napier grass has not doubled proportionally in relation to the diploid genome of millet, since a more detailed analysis shows that the largest chromosomes of Napier grass are close in size, with some, even superposing, the smaller chromosomes of millet (Table 1 and Figure 1 and 2). For BAG 54, the chromosomes 1 to 3 , with sizes varying from 3.72 to $4.68 \mu \mathrm{m}$, superpose the chromosomes 4 to 7 of M 36, with sizes within the interval of 3.41 to $4.68 \mu \mathrm{m}$. As for BAG 63 , the superposition is observed in the chromosomes 1 to 4 , measuring from 3.56 to $4.77 \mu \mathrm{m}$, with chromosomes 3 to 7 of M 36 measuring from 3.41 to $4.77 \mu \mathrm{m}$ (Table 1).

A recent study carried out by Reis et al. (2014) also demonstrates that, although smaller than the chromosomes of pearl millet, the chromosomes of Napier grass do not correspond exactly to half of those of millet, since the TLHL of the tetraploid genome does not double proportionally to the diploid genome of millet. This fact was demonstrated in the present work when the parental chromosomes are identified in the hybrid combination using GISH, which allows separating the chromosomes from the parents (Figure 3). It can be observed that some chromosomes marked with genomic probe of millet (evidenced in green) present length superposed to the chromosomes of Napier grass (predominantly blue); the two largest chromosomes of Napier grass are larger than the smallest chromosome of millet in the hybrid, as verified through the mean values of length for each chromosome, shown in Figure 3. 


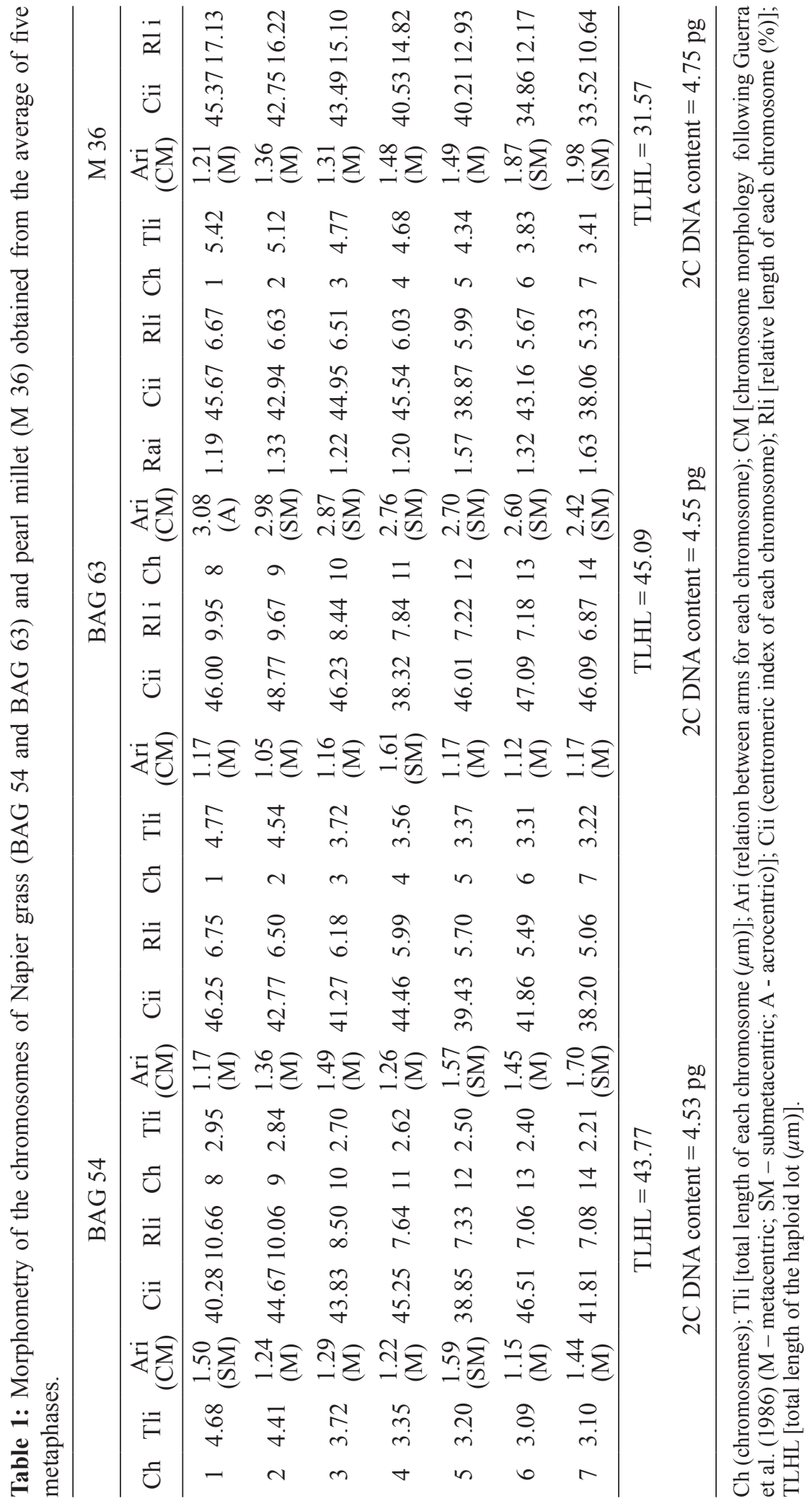


Table 2: Morphometry of the chromosomes from the triploid hybrids of Napier grass and pearl millet (H1 e H2) obtained from the average of five metaphases.

\begin{tabular}{|c|c|c|c|c|c|c|c|c|c|}
\hline \multicolumn{5}{|c|}{ H1 (BAG 54 x M 36) } & \multicolumn{5}{|c|}{ H2 (BAG $63 \times$ M 36) } \\
\hline $\mathrm{Ch}$ & Tli & Ari (CM) & Cii & Rli & $\mathrm{Ch}$ & Tli & Ari (CM) & Cii & Rli \\
\hline 1 & 5.14 & $1.10(\mathrm{M})$ & 47.58 & 7.67 & 1 & 5.34 & $1.64(\mathrm{SM})$ & 37.83 & 7.97 \\
\hline 2 & 4.74 & $1.33(\mathrm{M})$ & 42.92 & 7.07 & 2 & 5.04 & $1.02(\mathrm{M})$ & 49.60 & 7.52 \\
\hline 3 & 4.58 & $1.27(\mathrm{M})$ & 44.05 & 6.84 & 3 & 4.84 & $1.18(\mathrm{M})$ & 45.87 & 7.22 \\
\hline 4 & 4.32 & $1.00(\mathrm{M})$ & 50.00 & 6.44 & 4 & 4.48 & $1.55(\mathrm{SM})$ & 39.29 & 6.69 \\
\hline 5 & 4.27 & $1.27(\mathrm{M})$ & 44.13 & 6.37 & 5 & 4.22 & $1.32(\mathrm{M})$ & 43.13 & 6.30 \\
\hline 6 & 3.84 & $1.74(\mathrm{SM})$ & 36.56 & 5.73 & 6 & 4.08 & $1.65(\mathrm{SM})$ & 37.75 & 6.09 \\
\hline 7 & 3.76 & 1.57 (SM) & 38.92 & 5.62 & 7 & 3.92 & $1.09(\mathrm{M})$ & 47.96 & 5.85 \\
\hline 8 & 3.38 & $1.83(\mathrm{SM})$ & 35.33 & 5.04 & 8 & 3.62 & $1.45(\mathrm{M})$ & 40.88 & 5.40 \\
\hline 9 & 3.03 & $1.07(\mathrm{M})$ & 48.25 & 4.52 & 9 & 3.44 & $1.05(\mathrm{M})$ & 48.84 & 5.13 \\
\hline 10 & 2.92 & $1.21(\mathrm{M})$ & 45.26 & 4.36 & 10 & 3.32 & $1.13(\mathrm{M})$ & 46.99 & 4.96 \\
\hline 11 & 2.73 & $1.53(\mathrm{SM})$ & 39.53 & 4.08 & 11 & 3.08 & $1.08(\mathrm{M})$ & 48.05 & 4.60 \\
\hline 12 & 2.62 & $1.32(\mathrm{M})$ & 43.09 & 3.91 & 12 & 3.06 & $1.07(\mathrm{M})$ & 48.37 & 4.57 \\
\hline 13 & 2.56 & $1.80(\mathrm{SM})$ & 35.77 & 3.82 & 13 & 3.04 & $1.24(\mathrm{M})$ & 44.74 & 4.54 \\
\hline 14 & 2.44 & $1.38(\mathrm{M})$ & 42.11 & 3.64 & 14 & 2.88 & $1.32(\mathrm{M})$ & 43.06 & 4.30 \\
\hline 15 & 2.34 & $1.47(\mathrm{M})$ & 40.54 & 3.50 & 15 & 2.84 & $1.09(\mathrm{M})$ & 47.89 & 4.24 \\
\hline 16 & 2.34 & $1.52(\mathrm{SM})$ & 39.64 & 3.49 & 16 & 2.82 & $1.47(\mathrm{M})$ & 40.43 & 4.21 \\
\hline 17 & 2.22 & $1.42(\mathrm{M})$ & 41.28 & 3.31 & 17 & 2.66 & $1.02(\mathrm{M})$ & 49.62 & 3.97 \\
\hline 18 & 2.19 & $1.27(\mathrm{M})$ & 44.04 & 3.26 & 18 & 2.62 & $1.15(\mathrm{M})$ & 46.56 & 3.91 \\
\hline 19 & 2.14 & $1.61(\mathrm{SM})$ & 38.32 & 3.20 & 19 & 2.54 & $3.10(\mathrm{~A})$ & 24.41 & 3.79 \\
\hline 20 & 1.98 & $1.18(\mathrm{M})$ & 45.92 & 2.96 & 20 & 2.54 & $1.23(\mathrm{M})$ & 44.88 & 3.79 \\
\hline 21 & 1.85 & $1.41(\mathrm{M})$ & 41.49 & 2.75 & 21 & 2.48 & $1.00(\mathrm{M})$ & 50.00 & 3.70 \\
\hline \multicolumn{5}{|c|}{ TLHL $=65.39$} & \multicolumn{5}{|c|}{$\mathrm{TLHL}=72.86$} \\
\hline \multicolumn{5}{|c|}{$2 \mathrm{C} \mathrm{DNA} \mathrm{content}=4.51 \mathrm{pg}$} & \multicolumn{5}{|c|}{$2 \mathrm{C} \mathrm{DNA}$ content $=4.49 \mathrm{pg}$} \\
\hline
\end{tabular}

Chrom. (chromosomes); Tli [total length of each chromosome $(\mu \mathrm{m})$ ]; Ari (arm ratio for each chromosome); CM [chromosome morphology following Guerra et al. (1986) (M - metacentric; SM - submetacentric; A - acrocentric)]; Cii (centromeric index of each chromosome) Rli [relative length of each chromosome (\%)]; TLHL [total length of the haploid lot $(\mu \mathrm{m})$ ].

Taking as reference the values of Tli, Rli and TLHL observed in the parents Napier grass (BAG 54 and BAG 63) and pearl millet (M 36) (Table 1), inferences can be made about the morphological alterations occurring after the hybridization event in the hybrids $\mathrm{H} 1$ and $\mathrm{H} 2$. In $\mathrm{H} 1$, it was expected to find chromosomes with lengths varying between 2.38 and $5.42 \mu \mathrm{m}$, TLHL of $75.62 \mu \mathrm{m}$, and 2C DNA content of $4.64 \mathrm{pg}$ (Table 3). As for the hybrid H2, the same 2C DNA content (4.64 pg) was expected, as well as chromosome lengths varying from 2.42 to $5.42 \mu \mathrm{m}$, and
TLHL of $77.60 \mu \mathrm{m}$ (Table 3 ). However, it was observed that, on average, the hybrids presented TLHL ranging from 65.39 to $72.86 \mu \mathrm{m}$, respectively, for $\mathrm{H} 1$ and $\mathrm{H} 2$ (Table 2), which represents a reduction of $13.6 \%(\mathrm{H} 1)$ or $6.2 \%(\mathrm{H} 2)$ in the expected TLHL (Table 3$)$. When the DNA content is considered, a loss of $3 \%$ was observed for both hybrids, equivalent to $0.14 \mathrm{pg}$ of DNA (Tables 2 and 3 ). This amount of DNA correspond to about $2 \mu \mathrm{m}$ in length, thus the elimination of DNA content observed is significative as it is equivalent a one chromosome of the genome. 

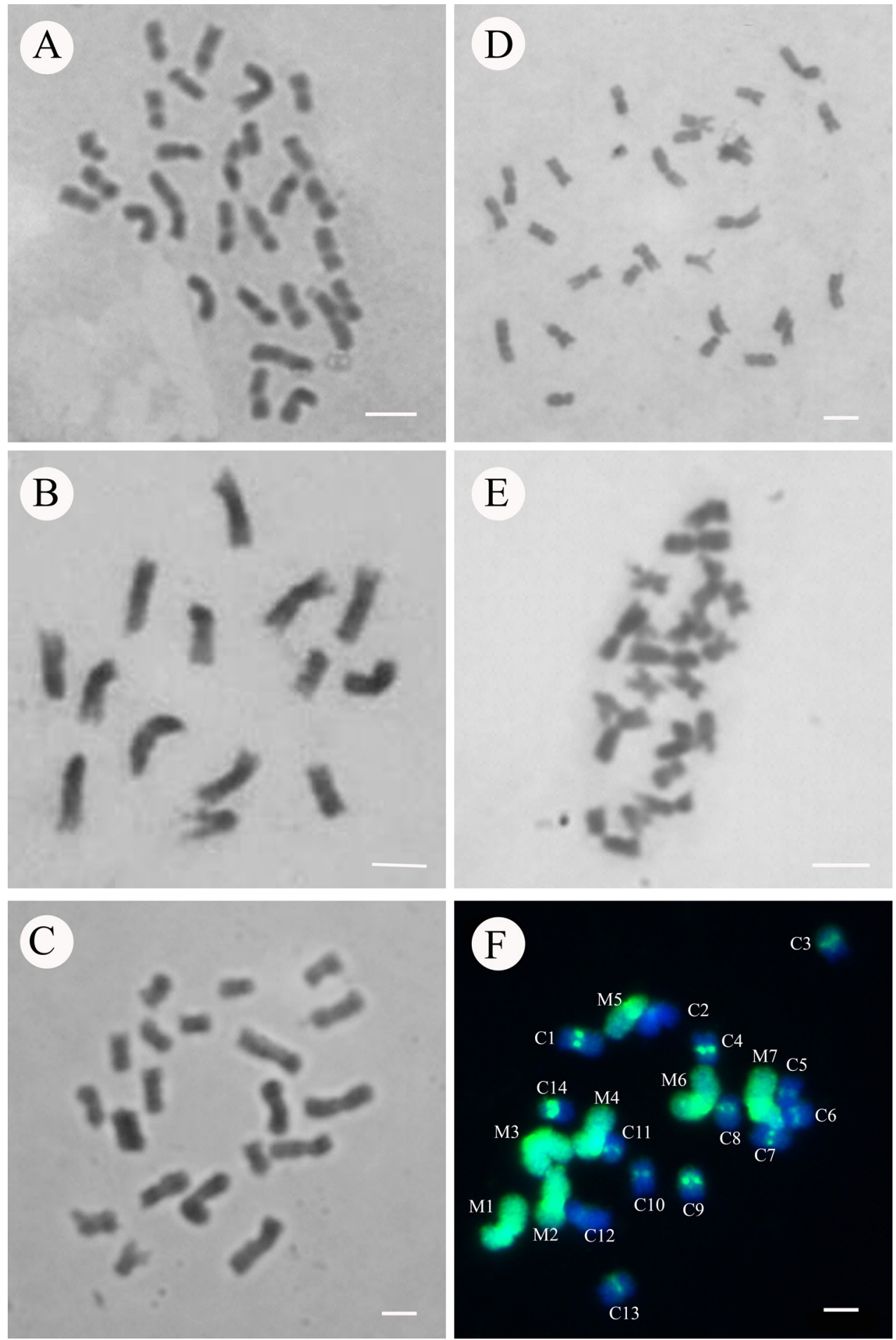

Figure 1: Metaphases from the genotypes analyzed in the present study. Representative Parental Napier grass $(2 \mathrm{n}=4 \mathrm{x}=28)$, BAG $63(\mathrm{~A})$ and BAG $54(\mathrm{D})$; female parental pearl millet $(2 \mathrm{n}=2 \mathrm{x}=14)$, M 36 (B); triploid interspecific hybrid $(2 \mathrm{n}=3 \mathrm{x}=21) \mathrm{H} 1(\mathrm{C}), \mathrm{H} 2(\mathrm{E})$ and $(\mathrm{F})$ GISH metaphase identifying pearl millet $\left(\mathrm{M}_{\mathrm{x}}\right)$ and Napier grass $\left(\mathrm{C}_{\mathrm{x}}\right)$ chromosomes in hybrid. Bar $=10 \mu \mathrm{m}$. 


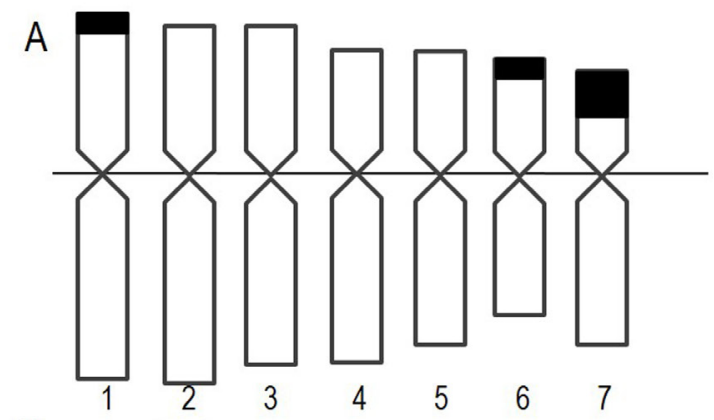

Primary constrictions

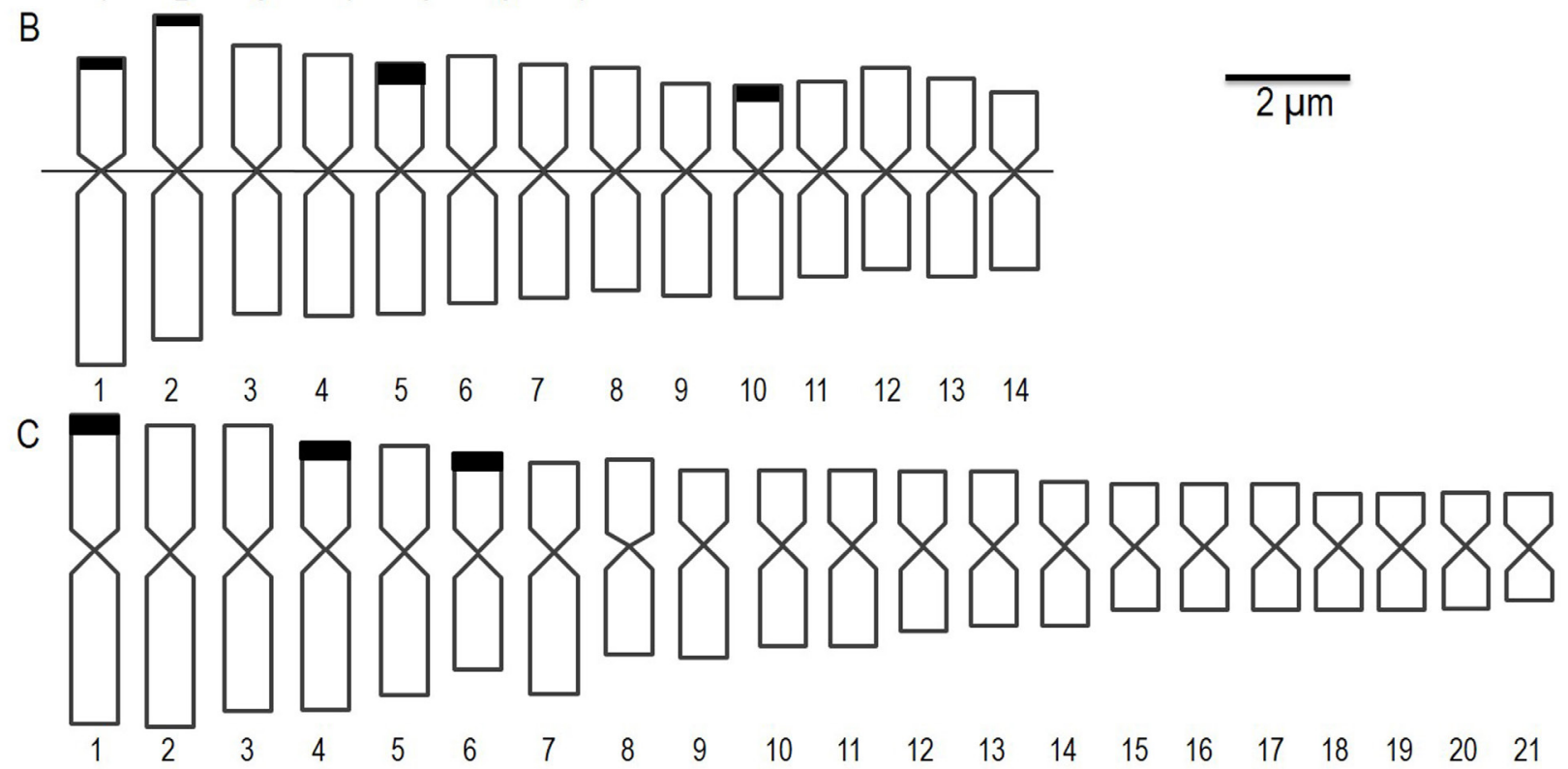

Figure 2: Ideograms from the genotypes analyzed in the present study. Representative Parental parental pearl millet $(2 \mathrm{n}=2 \mathrm{x}=14)(\mathrm{A})$ and Napier grass $(2 \mathrm{n}=4 \mathrm{x}=28)(\mathrm{B})$ and triploid interspecific hybrid $(2 \mathrm{n}=3 \mathrm{x}=21)(\mathrm{C})$.

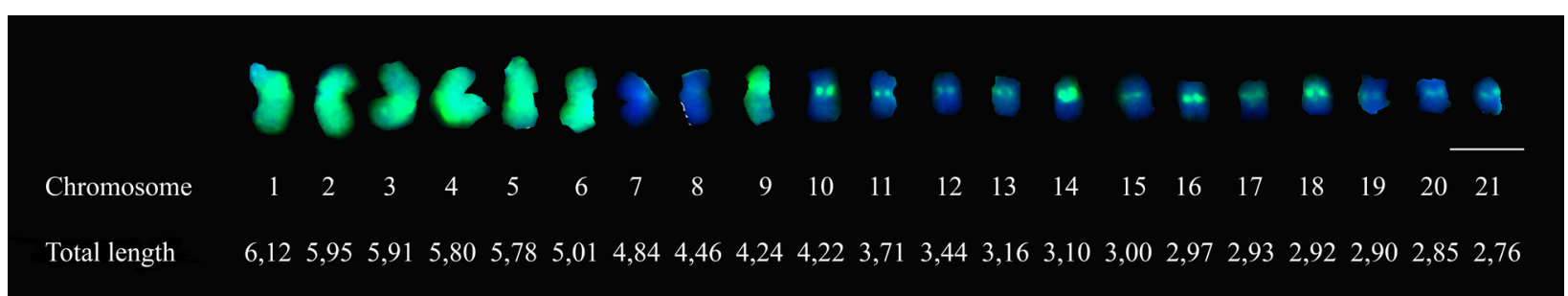

Figure 3: Genomic in situ hybridization in hybrids of Napier grass and millet $(2 n=3 x=21)$. Millet chromosomes are evidenced with genomic probe M marked with avidin (green) and Napier grass chromosomes are identified with DAPI (predominantly blue). Bar $=5 \mu \mathrm{m}$. 
Table 3: Contribution of the total length expected for the chromosomes of each one of the parents, Napier grass (C) and millet (M), in the triploid hybrids ( $\mathrm{H} 1$ and $\mathrm{H} 2)$.

\begin{tabular}{|c|c|c|c|c|c|c|c|}
\hline \multicolumn{5}{|c|}{ H1 (BAG 54 x M 36) } & \multicolumn{3}{|c|}{ H2 (BAG 63 x M 36) } \\
\hline Chrom. & Chrom. Parent & Tli & Rli & Chrom. & Chrom. & Tli & Rli \\
\hline 1 & $1-M$ & 5.42 & 7.16 & 1 & $1-M$ & 5.42 & 6.98 \\
\hline 2 & 2- $M$ & 5.12 & 6.78 & 2 & 2- $M$ & 5.12 & 6.60 \\
\hline 3 & $3-M$ & 4.77 & 6.31 & 3 & $3-M$ & 4.77 & 6.15 \\
\hline 4 & 4- $M$ & 4.68 & 6.19 & 4 & $1-\mathrm{C}$ & 4.77 & 6.14 \\
\hline 5 & $1-\mathrm{C}$ & 4.62 & 6.11 & 5 & 4- $M$ & 4.68 & 6.04 \\
\hline 6 & 2- $\mathrm{C}$ & 4.35 & 5.75 & 6 & $2-\mathrm{C}$ & 4.54 & 5.85 \\
\hline 7 & $5-M$ & 4.34 & 5.73 & 7 & $5-M$ & 4.34 & 5.59 \\
\hline 8 & 6- M & 3.83 & 5.06 & 8 & 6- $M$ & 3.83 & 4.93 \\
\hline 9 & 3- $\mathrm{C}$ & 3.51 & 4.64 & 9 & 3- $\mathrm{C}$ & 3.82 & 4.93 \\
\hline 10 & 7- $M$ & 3.41 & 4.51 & 10 & 4- $\mathrm{C}$ & 3.56 & 4.59 \\
\hline 11 & 4- $\mathrm{C}$ & 3.39 & 4.48 & 11 & 7- $M$ & 3.41 & 4.40 \\
\hline 12 & 5- $\mathrm{C}$ & 3.28 & 4.34 & 12 & 5- $\mathrm{C}$ & 3.37 & 4.34 \\
\hline 13 & 6- $C$ & 3.24 & 4.28 & 13 & 6- $\mathrm{C}$ & 3.31 & 4.27 \\
\hline 14 & 7- $\mathrm{C}$ & 3.12 & 4.13 & 14 & 7- $\mathrm{C}$ & 3.22 & 4.15 \\
\hline 15 & 8- $\mathrm{C}$ & 2.94 & 3.89 & 15 & 8- C & 3.08 & 3.97 \\
\hline 16 & 9- $\mathrm{C}$ & 2.78 & 3.68 & 16 & 9- $\mathrm{C}$ & 2.98 & 3.85 \\
\hline 17 & 10- C & 2.65 & 3.50 & 17 & $10-\mathrm{C}$ & 2.87 & 3.70 \\
\hline 18 & 11- C & 2.64 & 3.49 & 18 & $11-\mathrm{C}$ & 2.76 & 3.56 \\
\hline 19 & $12-\mathrm{C}$ & 2.60 & 3.44 & 19 & $12-\mathrm{C}$ & 2.70 & 3.48 \\
\hline 20 & $13-\mathrm{C}$ & 2.55 & 3.37 & 20 & $13-\mathrm{C}$ & 2.60 & 3.35 \\
\hline 21 & 14- C & 2.38 & 3.15 & 21 & 14- C & 2.42 & 3.12 \\
\hline \multicolumn{5}{|c|}{$\mathrm{TLHL}=75.62$} & \multicolumn{3}{|c|}{$\mathrm{TLHL}=77.60$} \\
\hline \multicolumn{5}{|c|}{$2 \mathrm{C} \mathrm{DNA}$ content $=4.64 \mathrm{pg}$} & \multicolumn{3}{|c|}{ 2C DNA content $=4.64 \mathrm{pg}$} \\
\hline
\end{tabular}

Chrom. (chromosomes); Tli [total length of each chromosome $(\mu \mathrm{m})$ ]; Rli [relative length of each chromosome (\%)]; TLHL [total length of the haploid lot $(\mu \mathrm{m})]$.

The loss of DNA in the hybrid is reflected on the alteration in the proportion of parental genomes in the hybrid nucleus. Based on the parental chromosomes observed in metaphases stained with DAPI, after GISH, it was expected to find a proportion of 1:0.9 from the genome of Napier grass to the genome of pearl millet, seeing that, on average, the total length of the diploid lot of $64.79 \mu \mathrm{m}$ was seen for Napier grass, and $58.63 \mu \mathrm{m}$ for millet. Nevertheless, in the evaluated metaphases of hybrids a mean proportion of 1:0.8 was observed, corresponding to $47.26 \mu \mathrm{m}$ from Napier grass to $38.81 \mu \mathrm{m}$ from millet chromosomes (Figure 3 ).

These results make evident the loss of DNA content, a genomic alteration resulting from hybridization.
According to Feldman et al. (1997) and Liu et al. (1996), a specific elimination of DNA sequences occurs in the first stages after hybridization. For the triploid hybrids of Napier grass and millet there is a reduction of 4 to $6 \%$ in the DNA content of hybrid embryos at 30 days after fertilization (Campos, unpublished data). Nunes et al. (2013) verified that the genomic instability in these hybrids is progressive, with greater reduction in DNA content on the $30^{\text {th }}$ day in relation to the $10^{\text {th }}$ day after fertilization.

In this work, the triploid hybrids have had approximately ten years of establishment in the field, with the loss of DNA appearing to be an already established 
consequence of hybridization. For other hybrids of Napier grass and millet under the same field conditions, losses of about 15\% were reported for TLHL (Barbosa; Davide; Pereira, 2003), and of 0 to $2.16 \%$ in the DNA content (Leão et al., 2011). These results demonstrate that, although very frequent, the reduction in the chromosome complement and DNA amount varies among triploid hybrids of Napier grass and pearl millet, indicating the better or worse adaptation of these hybrids in response to hybridization.

Besides detecting the loss of DNA, the morphometric data allowed morphological characteristics of the chromosomes of Napier grass and pearl millet to be verified and compared, being possible to detect other genomic alterations arising from hybridization. In Napier grass, three submetacentric chromosomes were observed: 5, 12 and 14 in BAG 54, and 4, 12 and 14 in BAG 63. The remaining chromosomes, for both genotypes, are metacentric (Table 1) according to Guerra (1986). Pearl millet showed the first five chromosomes to be metacentric (Ra varying from 1.0 to 1.49 ) and the two last chromosomes to be submetacentric (varying from 1.5 to 2.99 ). This way, it was expected to find at least five submetacentric chromosomes in the interspecific hybrid, with two coming from millet and three from Napier grass. Nevertheless, the karyotypic formula $14 \mathrm{~m}+7 \mathrm{sm}$ was observed for the hybrid $\mathrm{H} 1$, and $17 \mathrm{~m}+3 \mathrm{sm}+1$ ac for the hybrid H2 (Table 2).

The modifications in the karyotypic formulas, with increase in submetacentric chromosomes and occurrence of one acrocentric chromosome in the hybrid $\mathrm{H} 2$, suggest the incidence of breaks that lead to DNA loss, as well as of structural alterations in the hybrid combinations. The elimination of sequences in the hybrids of Napier grass and pearl millet was demonstrated in this and other works already cited; in addition, the occurrence of translocations and inversions was verified by the presence of multivalents with configurations of eight, chains, and by simple and multiple bridges in meiotic studies (Paiva et al., 2012). The fact that the parental genomes present high degree of homeology (Techio; Davide; Pereira, 2005; Reis et al., 2014) may also explain the occurrence of irregular pairings, unbalanced exchanges, loss of dispensable sequences, all of which are events commonly observed after hybridization. Most of the studies carried out with regards to the genetic consequences of hybridization are based on crossings between cultivated plants (cotton, wheat, Nicotiana, Brassica, Hordeum, among others), and in model plants like Arabidopsis (Bowers et al., 2003; Chen et al., 2004;
Simillion et al., 2002). Studies have shown that, once hybridization or polyploidy has occurred, whatever the mechanism involved, the resulting combination evolves rapidly (Chen; Ni, 2006).

Riddle and Birchler (2003) related that the new genomic constitution, produced after interspecific fertilization, leads to genetic and epigenetic reorganizations as a consequence of two different parental genomes coming together within one nucleus. This may lead to alterations in the number and distribution of DNA sequences, which may cause intergenic conflicts and loss of chromosomes. Therefore, the alterations observed in the hybrids of Napier grass and pearl millet may be the result of proximity and genic superposition, in function of the genomic proximity of the two species involved in obtaining the hybrid, besides the stabilization of a new nucleus in face of the hybrid combination. Nevertheless, the observed alterations were not equal in the evaluated hybrids, indicating that the changes in the complements do not follow the same pattern in all hybrids of Napier grass and pearl millet. This fact demonstrates that the arising genomic alterations probably depend on the genotype, and are not the same for a hybrid of the same parent species.

Ozkan, Tuna and Arumuganathan (2003) demonstrated results similar to those found in this work, estimating the DNA content by flow cytometry in newly synthesized hybrids of Aegilops and Triticum. The authors observed a reduction in the DNA content, in relation to the expected (mean of the parents involved in the crossing), of 5 to $7 \%$ in the genome size, totaling 2 pg of the $2 \mathrm{C}$ DNA content in one somatic cell. In addition, they observed that these alterations in the genome size occurred right at the first generation of amphidiploids, revealing the rapidity of the event. They suggest that these alterations, observed after allopolyploidization and without additive effect on the genome size, represent a pre-programmed adaptive response to the genomic stress caused by hybridization, which might have the function of stabilizing the genome of the new cell.

Other examples of non-additivity on the genome size were observed in Triticum (Liu; Vega; Feldman, 1998) and Aegilops (Shaked et al., 2001). Ma, Fang and Gustafson (2004) and Ma and Gustafson (2006) demonstrated that, in Triticum-Secale hybrids, $97 \%$ of the coding sequences of Triticum remained in the allopolyploids after 15 to 35 generations, whereas only $61.6 \%$ of the sequences of Secale were conserved.

Studies to certify that the hybrid presents alterations in the genic expression of rRNA genes are being developed, 
as well as studies that allow detecting alterations in the chromatin and genomic rearrangements. Works in this sense are important to help understand the karyotypic and genomic alterations that ensue after hybridization and polyploidization in hybrids of Pennisetum.

\section{CONCLUSIONS}

Genetic reorganizations were observed as a result of hybridization, such as the elimination of DNA sequences and chromosome rearrangements. These alterations were confirmed based on the size of the chromosomes, the DNA content and the karyotypic changes in the hybrids when compared with the parents.

In addition, it was demonstrated that the chromosomes of Napier grass and pearl millet have superposed (or similar) sizes, as verified by morphometric analysis via classic cytogenetics. Even in the hybrid combination, in which there are changes in the karyotypic formula, some size superpositions could be observed.

\section{REFERENCES}

ADAMS, K.L.; WENDEL, J.F. Novel patterns of gene expression in polyploid plants. Trends in Genetics: DNA differentiation \& development. 21(10):539-543, 2005.

ADOBE SYSTEMS. Adobe Photoshop 6.0 user guide. Adobe Systems, San Jose, CA. 2000.

ANDRADE-VIEIRA, L.F. et al. Biparental chromosome elimination in artificial interspecific hybrids Pennisetum purpureum Schum and P. glaucum (L.) R. Br. Crop Science. 53:1-8, 2013.

BARBOSA, S.; DAVIDE, L.C.; PEREIRA, A.V. Cytogenetics of Pennisetum purpureum (Schumack) $\mathrm{x}$ Pennisetum glaucum L. hybrids and their parents. Ciência e Agrotecnologia. 27(1):26-35, 2003.

BOWERS, J.E. et al. Unravelling angiosperm genome evolution by phylogenetic analysis of chromosomal duplication events. Nature. 422(6930):433-438, 2003.

CAMPOS, J.M.S. et al. In vitro induction of hexaploid plants from triploid hybrids of Pennisetum purpureum and Pennisetum glaucum. Plant Breeding. 128(1):101104, 2009.

CHEN, Z.J. et al. The development of an Arabidopsis model system for genome-wide analysis of polyploidy effects. Biological Journal of the Linnean Society. 82(4):689-700, 2004.

CHEN, Z.J.; NI, Z. Mechanisms of genomics rearrangements and gene expression changes in plant polyploids. BioEssays. 28(3):240-252, 2006.

DOYLE, J.J. et al. Evolutionary genetics of genome merger and doubling in plants. Annual Review of Genetics. 42:443-461, 2008.

DOYLE, J.J.; DOYLE, J.L. A rapid DNA isolation procedure for small quantities of fresh leaf tissue. Phytochem Bulletin. 19:11-15, 1987.

FELDMAN, M. et al. Rapid elimination of lowcopy DNA sequences in polyploid wheat: A possible mechanism for differentiation of homoeologous chromosome. Genetics. 147(3):1381-1387, 1997.

GAETA, R.T.J. et al. Genomic changes in resynthesized Brassica napus and their effect on gene expression and phenotype. The Plant Cell. 19(11):3403-3417, 2007.

GERMAND, D. et al. Uniparental chromosome elimination at mitosis and interphase in wheat and pearl millet crosses involves micronucleus formation, progressive heterochromatinization, and DNA fragmentation. The Plant Cell. 17(9):2431-2438, 2005.

GUERRA, M.D. Reviewing the chromosome nomenclature of Levan et al. Revista Brasileira de Genética. 9(4):741-743, 1986.

HANNA, W.W. Melhoramento do capim-elefante. In: PASSOS, L. P. et al. Biologia e manejo do capimelefante. Juiz de Fora: Embrapa Gado de Leite, 1999. p. $17-28$.

ISHII, T. et al. Chromosome elimination by wide hybridization between Triticeae or oat plant and pearl millet: pearl millet chromosome dynamics in hybrid embryo cells. Chromosome Research. 18(7):821-831, 2010.

KASHKUSH, K.; FELDMAN, M.; LEVY, A.A. Gene loss, silencing and activation in a newly synthesized wheat allotetraploid. Genetics. 160(4):1651-1659, 2002. 
KASHKUSH, K.; FELDMAN, M.; LEVY, A.A. Transcriptional activation of retrotransposons alters the expression of adjacent genes in wheat. Nature Genetics. 33(1):102-106, 2003.

LEÃO, F.F. et al. Genomic behavior of hybrid combinations between elephant grass and pearl millet. Pesquisa Agropecuária Brasileira. 46(7):712-719, 2011.

LEE, H.S.; CHEN, Z.J. Protein-coding genes are epigenetically regulated in Arabidopsis polyploids.

Proceedings of the National Academy of Sciences of the United States of America. 98(12):6753-6758, 2001.

LEITCH, I.J.; BENNETT, M.D. Genome downsizing in polyploid plants. Biological Journal of the Linnean Society. 82(4):651-663, 2004.

LEVY, A.A.; FELDMAN, M. Genetic and epigenetic reprogramming of the wheat genome upon allopolyploidization. Biological Journal of the Linnean Society. 82(4):607-613, 2004.

LIU, B.; VEGA, J.M.; FELDMAN, M. Rapid genomic changes in newly synthetized amphiploids of Triticum and Aegilops II. Changes in low-copy DNA sequences. Genome. 41:535-542, 1998.

LIU, S.C. et al. Genomewide high-resolution mapping by recurrent intermating using Arabidopsis thaliana as a model. Genetics. 142:247-258, 1996.

LUKENS, L.N. et al. Patterns of sequence loss and cytosine methylation within a population of newly resynthesized Brassica napus allopolyploids. Plant Physiology. 140(1):336-348, 2006.

MA, X.F.; FANG, P.; GUSTAFSON, J.P. Polyploidization-induced genome variation in triticale. Genome. 47(5):839-848, 2004.

MA, X.F.; GUSTAFSON, J.P. Timing and rate of genome variation in triticale following allopolyploidization. Genome. 49:950-958, 2006.

MARTEL, E. et al. Chromosome evolution of Pennisetum species (Poaceae): implications of ITS phylogeny. Plant Systematics and Evolution. 249(3/4):139-149, 2004.
MARTEL, E. et al. Genome size variation and basic chromosome number in pearl millet and fourteen related Pennisetum species. Journal of Heredity. 88(2):139143, 1997.

NUNES, J.D. et al. DNA elimination in embryogenic development of Pennisetum glaucum $\mathrm{x}$ Pennisetum purpureum (Poaceae) hybrids. Genetics and Molecular Research. 12(4):4817-4826, 2013.

OZKAN, H.; TUNA, M.; ARUMUGANATHAN, $\mathrm{K}$. Nonadditive changes in genome size during allopolyploidization in the wheat (AegilopsTriticum) group. Journal of Heredity. 94:260-264, 2003.

PAIVA, E.A.A. et al. Meiotic behavior in early and recent duplicated hexaploid hybrids of napier grass (Pennisetum purpureum) and pearl millet (Pennisetum glaucum). Caryologia: International Journal of Cytology, Cytosystematics and Cytogenetics. 65(2):114-120, 2012.

PEREIRA, A.V. et al. Variação da qualidade de folhas em capim-elefante (Pennisetum purpureum) e híbridos de capim-elefante $\mathrm{x}$ milheto $(P$. purpureum x $P$. glaucum), em função da idade da planta. Ciência e Agrotecnologia. 24(2):490-499, 2000 .

PIRES, J.C. et al. Flowering time divergence and genomic rearrangements in resynthesized Brassica polyploids (Brassicaceae). Biological Journal of the Linnean Society. 82(4):675-688, 2004.

PONTES, O. et al. Chromosomal locus rearrangements are a rapid response to formation of the allotetraploid Arabidopsis suecica genome. Proceedings of the National Academy of Sciences of the United States of America. 101(52):18240-18245, 2004.

REIS, G.B. et al. Genomic homeologybetween Pennisetum purpureum and Pennisetum glaucum (Poaceae). Comparative Cytogenetics. 8(3):199-209, 2014.

RIDDLE, N.C.; BIRCHLER, J.A. Effects of reunited diverged regulatory hierarchies in allopolyploids and species hybrids. Trends in Genetics. 19(11):597-600, 2003. 
SALMON, A.; AINOUCHE, M.L.; WENDEL, J. F. Genetics and epigenetics consequences of recent hybridization and polyploidy in Spartina (Poaceae). Molecular Ecology. 14(4):1163-1175, 2005.

SANEI, M. et al. Loss of centromeric histone H3 (CENH3) from centromeres precedes uniparental chromosome elimination in interspecific barley hybrids. Plant Biology. 108(33):498-505, 2011.

SHAKED, H. et al. Sequence elimination and cytosine methylation are rapid and reproducible responses of the genome to wide hybridization and allopolyploidy in wheat. The Plant Cell. 13:1749-1759, 2001.
SIMILLION, C. et al. The hidden duplication past of Arabidopsis thaliana. Proceedings of the National Academy of Sciences of the United States of America. 99(21):13627-13632, 2002.

TECHIO, V.H.; DAVIDE, L.C.; PEREIRA, A.V. P. Genomic analysis in Pennisetum purpureum and $P$. glaucum hybrids. Caryologia. 8(1):28-33, 2005.

UDALL, J.A.; QUIJADA, P.A.; OSBORN, T.C. Detection of chromosomal rearrangements derived from homeologous recombination in four mapping populations of Brassica napus L. Genetics. 169(2):967979, 2005. 